Article

\title{
Iron-Rich Magnetic Coal Fly Ash Particles Induce Apoptosis in Human Bronchial Cells
}

\author{
Matthew J. Lawson ${ }^{1}{ }^{(\mathbb{B}}$, Zoe C. Prytherch ${ }^{1}$, Tim P. Jones ${ }^{2}$, Rachel A. Adams ${ }^{3}{ }^{\circledR}$ and \\ Kelly A. BéruBé 1,*iD \\ 1 School of Biosciences, Cardiff University, Museum Avenue, Cardiff CF10 3AX, UK; \\ m.j.lawson@soton.ac.uk (M.J.L.); prytherchzc@cardiff.ac.uk (Z.C.P.) \\ 2 School of Earth and Ocean Science, Cardiff University, Park Place, Cardiff CF10 3AT, UK; \\ jonestp@cardiff.ac.uk \\ 3 Cardiff School of Health Sciences, Cardiff Metropolitan University, Western Avenue, Cardiff CF5 2YB, UK; \\ RAdams@cardiffmet.ac.uk \\ * Correspondence: BeruBe@cardiff.ac.uk
}

Received: 2 October 2020; Accepted: 19 November 2020; Published: 25 November 2020

check for updates

\begin{abstract}
Svalbard is an arctic archipelago where coal mining generates all electricity via the local coal-fired power station. Coal combustion produces a waste product in the form of particulate matter (PM) coal fly ash (CFA), derived from incombustible minerals present in the feed coal. PM $\leq 10 \mu \mathrm{m}$ (diameter) may be "inhaled" into the human respiratory system, and particles $\leq 2.5 \mu \mathrm{m}$ may enter the distal alveoli to disrupt normal pulmonary functions and trigger disease pathways. This study discovered that Svalbard CFA contained unusually high levels of iron-rich magnetic minerals that induced adverse effects upon human lungs cells. Iron is a well-characterised driver of reactive oxygen species (ROS) generation, a driving force for cell death and disease. CFA physicochemical characterisation showed non-uniform particle morphologies indicative of coal burnt at inefficient combustion temperatures. The bioreactivity (ROS generation) of $\mathrm{PM}_{2.5 / 10}$ fractions was measured using plasmid scission assay (PSA, DNA damage) and haemolysis assays (erythrocyte lysis), with $\mathrm{PM}_{2.5}$ CFA showing significant bioreactivity. CFA leached in mild acid caused a significant increase in toxicity, which could occur in CFA waste-stores. The CFA and leachates were exposed to a surrogate model of human bronchial epithelia that confirmed that CFA induced apoptosis in bronchial cells. This study shows that CFA containing magnetic iron-rich minerals mediated adverse reactions in the human lung, and thus CFA should be considered to be an environmental inhalation hazard.
\end{abstract}

Keywords: bioreactivity; cytotoxicity; coal fly ash; particulate matter; leachate; iron-rich minerals; Svalbard

\section{Introduction}

Svalbard is a small Norwegian archipelago located north of mainland Europe in the Arctic Circle. At the beginning of the 20th century, coal deposits were discovered, and since then coal mining has been a major industry on the islands [1]. The sole source of electricity for the islands comes from the coal-fired power station located on the outskirts of Longyearbyen. The coal is locally sourced from the two operating mines on Svalbard, which are run by Store Norske. Only a small portion of the coal is used in the small power station, the remainder is exported to mainland Europe to countries such as Germany, the Netherlands, and Denmark [2]. The coal mined on Svalbard is from the Paleocene epoch (66-56 Ma). Coal deposits on the islands from other geological periods are too small to be mined commercially [2]. The Cenozoic Central Basin of Svalbard contains both the mined coal deposits, Gruve 7 and Svea Nord, which are in the Todalen Member. This is mostly composed of less 
than 60 metres of thick rhythmic and coarsening upwards successions of shale-siltstone-sandstone, capped by either coal or clay ironstone [3]. The Longyearbyen Power Station burns 22,000 tons of coal each year from the two mines on Svalbard. Particulate matter (PM) released from the power station are categorised as being either "inhalable" (diameter less than $10 \mu \mathrm{m}\left(\mathrm{PM}_{10}\right)$ or "respirable" particles (diameter less than $2.5 \mu \mathrm{m}\left(\mathrm{PM}_{2.5}\right)$ [4]. Coal fly ash (CFA) is the combustion-derived PM that is formed as a by-product of fossil fuel combustion from the inorganic (i.e., incombustible) minerals present. CFA contributes to the burden of air pollution as a result of its direct release from power station stacks, or released indirectly from waste storage piles by wind resuspension [5]. During coal combustion, depending on the temperatures reached, mineral impurities can melt to form glass droplets and are carried along the hot gas stream in the furnace flue [6]. As the melted material travels, it cools and solidifies into multi-sized "dirty glass" spheres, which can be identified as CFA particles. The properties of the CFA depend on the physicochemical properties of the original coal, particle size, combustion processes, and the type of ash collector [7]. The inhalable fraction of most CFA consists predominantly of uniformly spherical particles but can also contain smaller agglomerates and fragments within the $\mathrm{PM}_{10}$ range. Smaller CFA spheres are typically $2-3 \mu \mathrm{m}$ in diameter but can aggregate to form larger structures [8]. Ferrous minerals can either be original coal minerals that failed to melt during combustion but might have undergone some geochemical change, or minerals that crystallised out of the glass in the CFA. The presence of crystallised "dendritic" iron oxides inside CFA is well established, however, the crystallisation sequence is still unclear [6]. The oxidative capacity of iron oxides in CFA has been well documented, stating that Fenton-like reactions result in reactive oxygen species (ROS) generation, specifically the hydroxyl radical $(\bullet \mathrm{OH})[9] . \mathrm{PM}_{10} \mathrm{CFA}$ can enter the respiratory tract with the smaller PM $(<2.5 \mu \mathrm{m})$ able to penetrate deep into the lungs [8]. Here, ROS generation caused by the CFA could cause significant damage to bronchial epithelial cells lining the respiratory tract.

In this study, we used a variety of geochemistry techniques to characterise the physicochemical properties of CFA collected in Svalbard. The characterised size fractions of PM10 CFA were put through a hierarchy of acellular in vitro bioreactivity assays that determine the presence of ROS. The bioreactivity of CFA samples was determined by using in vitro, three-dimensional, human-derived lung cell cultures of the bronchial epithelium. These results could provide fundamental data for the development of storage protocols and health risk assessments with respect to Svalbard CFA.

\section{Materials and Methods}

\subsection{CFA Collection and Processing}

The precipitated CFA was collected directly from the waste chutes underneath the electrostatic precipitation plates of the Longyearbyen power station by Dr Lisa Mol (Earth Sciences, Cardiff University) in 2014 and stored in sterile plastic containers, which were transported to Cardiff University for analysis. The bulk CFA was separated into $\mathrm{PM}_{2.5}$ and $\mathrm{PM}_{10}$ fractions using the dry dust separator devised and used by Jones et al. [10]. Briefly, the bulk CFA was placed inside a slowly rotating drum that was fitted with a HEPA (high-efficiency particulate air) filter at the air inlet end. As the drum rotates, the dust is suspended in the air by baffles, and the particles fall out of the air at a rate controlled by Stokes' law. The air flow rate is sequentially increased to collect larger size fractions. The air outlet end comprised a Negretti $\mathrm{PM}_{10}$ selective head with polycarbonate filters $(0.67 \mu \mathrm{m})$. The system uses a variable vacuum pump capable of generating different throughflow rates between 1 to 30 litres/minute. The flow rates used were 5 litres/minute to collect the PM2.5 fraction, followed by 10 litres/minute to collect the $\mathrm{PM}_{10}$ fraction. The particles sizes collected were confirmed by scanning electron microscopy (SEM), as the collected sizes are a function of the particle size, shape, and density. A magnetic separation of the CFA was also attempted using a high-powered neodymium magnet, a technique that has been successfully used for several U.K. and European CFAs and usually captures a small percentage of the bulk material, typically less than $5 \%$. However, for the Svalbard 
CFA, the entire bulk sample was magnetic and attached itself firmly to the magnet. On the basis of this experiment, we recorded that the entire CFA sample was magnetic, a unique result in our 20 years' experience. For a positive magnetic control, we commercially obtained pure crystals of the iron oxide mineral magnetite $\left(\mathrm{Fe}_{3} \mathrm{O}_{4}\right)$, which were then crushed and had the mineralogy confirmed by $\mathrm{X}$-ray diffraction. The sub-PM 10 size of the powdered magnetite sample (standard) was confirmed by SEM.

\subsection{Electron Microscopy}

The bulk and separated CFA were observed using a field emission scanning electron microscope (FE-SEM; Philips XI Series 30 Field Emission Scanning Electron Microscope), as described by Jones et al. [10]. SEM stubs were prepared with samples of $\mathrm{PM}_{2.5}, \mathrm{PM}_{10}$, bulk CFA, and finely powdered magnetite. Prior to imaging, the stubs were splutter coated with a gold/palladium mixture to a thickness of 20nm. A range of magnifications were used to obtain images of CFA for each size fraction to allow direct comparisons of the PM in terms of their morphology, surface texture, and size distributions. Smaller scale characterisation of the CFA particles were observed using a high-resolution transmission electron microscope (HRTEM). CFA was suspended in Molecular Biology-grade water $\left(\mathrm{MB}-\mathrm{H}_{2} \mathrm{O}\right)$ and, using a pipette, was placed on a TEM grid; the grid was then dried at room temperature. The CFA was observed under a JEM-2100 LaB6 Transmission Electron Microscope, with a high-resolution Gatan digital camera capable of a resolution of $0.02 \mathrm{~nm}$.

\subsection{Elemental Analysis}

Major chemical elements in the CFA were analysed using the FE-SEM (Philips XI Series 30) equipped with an energy-dispersive $X$-ray spectroscopy system (EDX). In combination with the SEM images, EDX can also visualise where specific major elements occur on an image. For CFA samples in solution (leachates), inductively coupled plasma-mass spectroscopy (ICP-MS) was undertaken; the leachates were acidified to $10 \%$ nitric acid and processed directly through the ICP-MS. The ICP was calibrated and checked using a Japanese basalt standard. The leachates were analysed using a Thermo-Elemental X-Series ICP-MS equipped with a Cetac AS-500 auto-sampler. Elements present in the solution were analysed on mass-to-charge ratios and compared to the geological standard.

\subsection{CFA Leachate Production}

Leachates were prepared from the dried PM samples using a method adapted from the British Standard (BS EN 12,457 Part 2) "characterisation of waste leaching test". These adaptations were a much smaller amount of leachate produced, and the range of times used was ( $24 \mathrm{~h}$ in BS EN 12,457 Part 2). Twenty milligrams of CFA was weighed out to an accuracy of $0.1 \mathrm{mg}$ and poured into a sterile $15 \mathrm{~mL}$ Falcon tube. The tube was filled with the leachate solutions up to $10 \mathrm{~mL}$, establishing a liquid-to-solid concentration of $2 \mathrm{mg} / \mathrm{mL}$. Five repeats of each leachate were created, and they were drawn off at 5 different time points: 1, 3, 5, 24, and $48 \mathrm{~h}$. The leachate solutions used were double-distilled (dd) $\mathrm{H}_{2} \mathrm{O}, \mathrm{pH} 6 \mathrm{HCl}, \mathrm{pH} 8 \mathrm{NaOH}$, "environmental water" (locally sourced from a stream in Cardiff), and human-derived lysozyme; a control from a previous CFA study of Aberthaw Power Station was also used for comparison.

\subsection{Plasma Scission Assay}

Each size fraction of separated CFA $\left(\mathrm{PM}_{2.5}\right.$ and $\left.\mathrm{PM}_{10}\right)$ and crushed magnetite were initially processed through the plasmid scission assay (PSA) by incubating them with the bacteriophage plasmid ФX 174 and analysed by gel electrophoresis. This was later repeated for the $\mathrm{PM}_{2.5}$ CFA leachates.

The plasmid $\varphi$ X174 RF DNA (1 mg/mL) was diluted to $200 \mu \mathrm{g} / \mathrm{mL}$ with Molecular Biology-grade water $\left(\mathrm{MB} \mathrm{H}_{2} \mathrm{O}\right)$; for the assay, $1 \mu \mathrm{L}$ of plasmid DNA was pipetted into $0.2 \mathrm{~mL}$ Eppendorfs prior to the sample being added. The CFA samples were first suspended in $\mathrm{MB}_{2} \mathrm{O}$ to a concentration of $2 \mathrm{mg} / \mathrm{mL}$ before they were sonicated for $5 \mathrm{~min}$. Following this, the CFA solutions were diluted further down to make a range of concentrations $(100,500,1000$ and $2000 \mu \mathrm{L})$. All CFA concentrations were vortexed 
immediately prior to use (to avoid concentration anomalies from particle sedimentation). Each CFA suspension was pipetted into the Eppendorfs containing the plasmid DNA $(n=4)$. Samples were incubated at room temperature for $6 \mathrm{~h}$ on a gently shaking vortex agitator at the lowest setting. The positive control for one lane of the gel used the Pst I enzyme kit and the negative control was the plasmid incubated with $\mathrm{MBH}_{2} \mathrm{O}$ (or solution used for the leachates when appropriate).

The gel used for electrophoresis contained $415 \mathrm{~mL}$ of $1 \times$ Tris-borate-ethylenediaminetetracetic acid (TBE), which was added to agarose $(5 \times 0.5 \mathrm{~g}$ tablets $)$ and heated to allow the tablets to dissolve. Once cooled, $10 \mu \mathrm{L}$ of ethidium bromide was added to the solution before it was poured out into a tray with 240 -teeth comb racks in. Following the $6 \mathrm{~h}$ incubation of the samples, $3.33 \mu \mathrm{L}$ of orange/blue loading dye was added, and each sample $(20 \mu \mathrm{L})$ was loaded into the wells in the gel, which had been placed in the electrophoresis tank. Ethidium bromide $(15 \mu \mathrm{L})$ was added to both reservoirs of the tank before running the gel at 30 volts for $16 \mathrm{~h}$ at room temperature. Once the gel had run for $16 \mathrm{~h}$, it was removed from the electrophoresis tank and placed in a dark room within the UVP Biospectrum imaging system for further analysis. A digital image of the gel was captured (Hamamatsu 12 bit CCD camera VisionWorks software, Ultraviolt Products), which was imported into Genetools software to allow densitometric quantification (giving the percentage of sample in each band of the gel).

The mean of each of the 4 replicates for CFA concentrations was used as the final value, which was then exported to Excel to present the results in graphical form. The relative amount of damaged DNA (relaxed and linear form, upper bands on gel) was calculated as a percentage of the super coiled intact DNA (lower band on gel). Average sample damage was represented as percentage of DNA damage against CFA concentration. Significance of the individual results was confirmed using a 1-way $t$-test, and significance between the different groups (CFA fractions/leachates) results were calculated using a 1-way ANOVA, with significance confirmed using Tukey's statistic in the R statistical software (v 3.1.1.).

\subsection{CFA Haemolysis Assay}

Each of the CFA size separations, the magnetite control, and the most toxic leachates (determined by PSA) were incubated with isolated human red blood cells (RBCs) and analysed by the Tecan Infinite 200 PRO plate reader at $\lambda 540 \mathrm{nms}$ for the haemolysis assay. Initially, $10 \mathrm{~mL}$ of blood was drawn from 3 donors by Dr Rachel Adams at Cardiff Metropolitan University. The blood samples were centrifuged at $3750 \mathrm{rpm}$ at $4{ }^{\circ} \mathrm{C}$ for $10 \mathrm{~min}$; the supernatant and thin layer of platelets were removed from the blood and discarded. The blood samples were re-suspended with $0.9 \%$ saline to reach back up to a total volume of $10 \mathrm{~mL}$, this was repeated 2 more times. Four $1 \mathrm{~mL}$ aliquots of each donor's RBCs were stored in Eppendorfs and centrifuged again at $1700 \mathrm{rpm}$ for $5 \mathrm{~min}$. The final working solution of diluted RBCs was made by adding $200 \mu \mathrm{L}$ from each of the four Eppendorfs to $7.2 \mathrm{~mL}$ of $0.9 \%$ saline to make $8 \mathrm{~mL}$. The CFA samples were prepared in the same manner as the PSA, except they were suspended in $0.9 \%$ phosphate buffered saline (PBS) with a concentration range starting from $4 \mathrm{mg} / \mathrm{mL}$.

The CFA solution $(125 \mu \mathrm{L})$ was added to the prepared blood $(125 \mu \mathrm{L})$ in a 96-well plate, which was then sealed with adhesive plastic and placed on a shaker for $10 \mathrm{~min}$. The plate was then centrifuged at $200 \mathrm{rpm}$ for $5 \mathrm{~min}$ at $4{ }^{\circ} \mathrm{C}$, and $100 \mu \mathrm{L}$ of supernatant was removed and placed into a corresponding well of a new 96-well plate. The negative control contained only $0.9 \%$ PBS and the positive control contained $0.1 \%$ Triton X-100 mixed with the prepared blood. The plate containing the supernatant had its optical density read using the Tecan Infinite $200 \mathrm{PRO}$ plate reader at $540 \mathrm{~nm}$. The absorbance readings in optical density from the plate reader was converted into percentage of haemolysis with the following formula: \%haemolysis $=[($ sample OD-control OD $) /($ standard OD - control OD $) \times 100]$.

\subsection{In Vitro Lung Cell Culture}

The normal human bronchial epithelial (NHBE) cells were commercially obtained from MatTek Corporation (USA). This air-liquid interface (ALI) in vitro human tissue model provides a physiologically relevant system for testing inhaled chemicals, including vapours, gases, and nanoparticles. The model is used to determine relative toxicity of environmental and occupational 
pollutants and the relative safety of inhaled drug formulations, tobacco, and e-products. Upon arrival of the "EpiAirway Air-100" cell cultures, we handled the cells according to the manufacturer's instructions. After the cells were equilibrated, the inserts were placed into 24-well plates with fresh pre-warmed media ( $3 \mathrm{~mL}$ ) ready for dosing. The CFA suspensions were made "fresh" with $\mathrm{H}_{2} \mathrm{O}$ just prior to dosing at a concentration of $2000 \mu \mathrm{g} / \mathrm{mL}$; the filtered leachates $\left(\mathrm{H}_{2} \mathrm{O} 48 \mathrm{~h}\right.$ and $\left.\mathrm{HCl} 48 \mathrm{~h}\right)$ had already been prepared. Apical exposure of the cells ( $n=6$ wells per dose) consisted of placing $50 \mu \mathrm{L}$ of solution onto the apical surface of the cell insert and were incubated for $24 \mathrm{~h}$ at $37^{\circ} \mathrm{C}$ with $5 \% \mathrm{CO}_{2}$.

The trans-epithelial electrical resistance (TEER) measurements required the use of an "epithelial volt-ohmmeter" (EVOM) with a two-tonged chopstick probe attached (Stix2). The cell inserts had $150 \mu \mathrm{L}$ of PBS dispensed onto the apical surface before being placed into a well of a 24-well plate, which was pre-filled with PBS $(800 \mu \mathrm{L})$; this was performed both prior and after cell dosing. The shorter tong of the probe was placed inside the insert and the longer one in the PBS in the well. The resistance between the two probes was recorded before and after cell dosing. TEER values were measured as $\Omega / \mathrm{cm} 2$ and expressed as a percentage of the control both prior and after dosing.

\subsection{Cell Viability Assay}

Cell viability was determined by the change in luminescence resulting from a change in the levels of intracellular adenosine triphosphate (ATP), as described by [11]. Following the $24 \mathrm{~h}$ incubation of the lung cells with the CFA PM and/or leachates, the viability of the cells in culture was measured $(n=4)$ using the ATP assay. The ATP-monitoring reagent (AMR) was reconstituted in Tris-borate-EDTA (ethylenediaminetetraacetic acid) buffer; cell lysis reagent $(100 \mu \mathrm{L})$ was added apically to the cell culture inserts (10 min; room temperature). The AMR buffer $(100 \mu \mathrm{L})$ was added to a 96 -well plate after the lysed cells $(100 \mu \mathrm{L})$, which were then also transferred into the 96-well plate. Samples were incubated ( $2 \mathrm{~min}$ in the dark), and the luminescence was measured by the LUMI star OPTIMA plate reader. Blank measurements (100 $\mu \mathrm{L}$ cell lysis reagent and $100 \mu \mathrm{L}$ AMR) were recorded, and their average absorbance was subtracted from all the average sample measurements. The culture viability was expressed as a percentage of the control.

\subsection{Cytotoxicity Assay}

Cytotoxicity was assessed by lactate dehydrogenase (LDH) released as described by [12]. The plate was read at an absorbance of $490 \mathrm{~nm}$ and $680 \mathrm{~nm}$ in the Tecan Infinite 200 PRO plate reader; in order to determine LDH activity, we deducted the background absorbance value $(680 \mathrm{~nm})$ from the desired absorbance value $(490 \mathrm{~nm})$, yielding the absorbance values that were used in calculating the percentage of cytotoxicity. LDH leakage assay was performed to measure the cytotoxicity of the CFA particles and leachates according to the manufacturer's protocol (Sigma). The LDH activity was determined using the following formula: \%cytotoxicity $=[($ sample OD-control OD) $/($ standard OD - control OD $) \times 100]$.

\subsection{Bradford Assay}

The Bradford assay was used to determine the protein concentration of the apical wash (i.e., how much protein had been secreted from the cells in response to the PM exposure/dose). The Bradford assay measured the protein levels by measuring absorbance at $595 \mathrm{~nm}$ on the Bio-Rad model 680 microplate reader; these results were then compared to a standard curve created using bovine serum albumin (BSA). The protein levels in the apical wash of the cells were expressed as a percentage of the control. 


\subsection{Histology}

Two of the cell culture inserts from each cell dose were designated for histology, and thus following the $24 \mathrm{~h}$ incubation, we fixed the cells by placing them into $1 \mathrm{~mL}$ of $10 \%$ neutral buffered formalin $\left(24 \mathrm{~h} ; 4^{\circ} \mathrm{C}\right)$. After $24 \mathrm{~h}$, they were transferred into PBS $(1 \mathrm{~mL})$ and stored at $4{ }^{\circ} \mathrm{C}$. The cell membrane was removed from the inserts using a scalpel and placed in PBS. The cells were then sectioned and stained with haematoxylin and eosin stain. The micrograph images were taken using a Leica Phase Contrast Light Microscope (DM2500) attached to a digital camera (Leica DFC 320) and images saved for analysis.

\section{Results}

This section may be divided by subheadings. It should provide a concise and precise description of the experimental results, their interpretation, as well as the experimental conclusions that can be drawn.

\subsection{Physicochemical Characterisation of Size-Separated CFA}

On the basis of FE-SEM morphological characteristics (Figure 1) and the EDX spectra, we could identify the Svalbard CFA as fly ash ( $\mathrm{Si}, \mathrm{Al}$, and $\mathrm{O}$ ), ferrospheres (Fe, $\mathrm{Al}$, and $\mathrm{O})$, soot particles (carbon), mineral particles ( $\mathrm{S}, \mathrm{O}, \mathrm{Ca}, \mathrm{Cl}$, and $\mathrm{Na}$ ), and unidentified particles [13]. The FE-SEM imaging of the $\mathrm{PM}_{2.5}$ (Figure 1A-C) fraction confirmed that the low air flow had separated out the smallest particles from the bulk CFA samples, with the majority of the particles being in the $\mathrm{PM}_{2.5}$ range. The morphology did not show uniform CFA spheres throughout the sample, and the spheres present did not have smooth surfaces. Small $\mathrm{PM}_{2.5}$ shards of glass were also found distributed throughout the $\mathrm{PM}_{2.5} \mathrm{CFA}$, as well as the mineral gypsum $\left(\mathrm{CaSO}_{4}\right)$ that was seen as clumps of feather-like crystals. The $\mathrm{PM}_{10} \mathrm{CFA}$ (Figure 1D-F) contained many different types of particle morphologies. Some particles were larger than the $\mathrm{PM}_{10}$ size range, but the majority of the separation was within the threshold. There were four basic morphologies discovered in the Svalbard $\mathrm{PM}_{10}$ fraction (Figure 1D). The bulk CFA (Figure 1G) samples consisted of a mixture of large shards of glass and large CFA spheres. The majority of these particles were larger than the $\mathrm{PM}_{10}$ threshold, and therefore the bulk CFA was not used in any geochemical or biochemical analysis. Magnetite $\left(\mathrm{Fe}_{3} \mathrm{O}_{4}\right)$, a magnetic iron oxide, was obtained to act as a positive control for the bioreactivity experiments. The SEM analysis confirmed that the magnetite was crushed (via a small geological pestle and mortar) from macroscopic crystals into $\mathrm{PM}_{10}$-sized particles (Figure $1 \mathrm{H}$ ).

Micro-characterisation of the smallest components of the CFA fractions was performed using HRTEM (Figure 2). The images revealed the crystalline structure of the carbon particles and showed that the iron-bearing ferrospheres were usually smaller than $2.5 \mu \mathrm{m}$ and that they were not crystalline. The calculated measurement of the carbon d-spacing between the lattices at the highest level of magnification was confirmed to be $3.4 \AA$ (Figure 2B). The large "fibrous" particles seen in the SEM images (Figure 1F) of the $\mathrm{PM}_{10}$ CFA were also seen in the TEM (Figure 2C). 

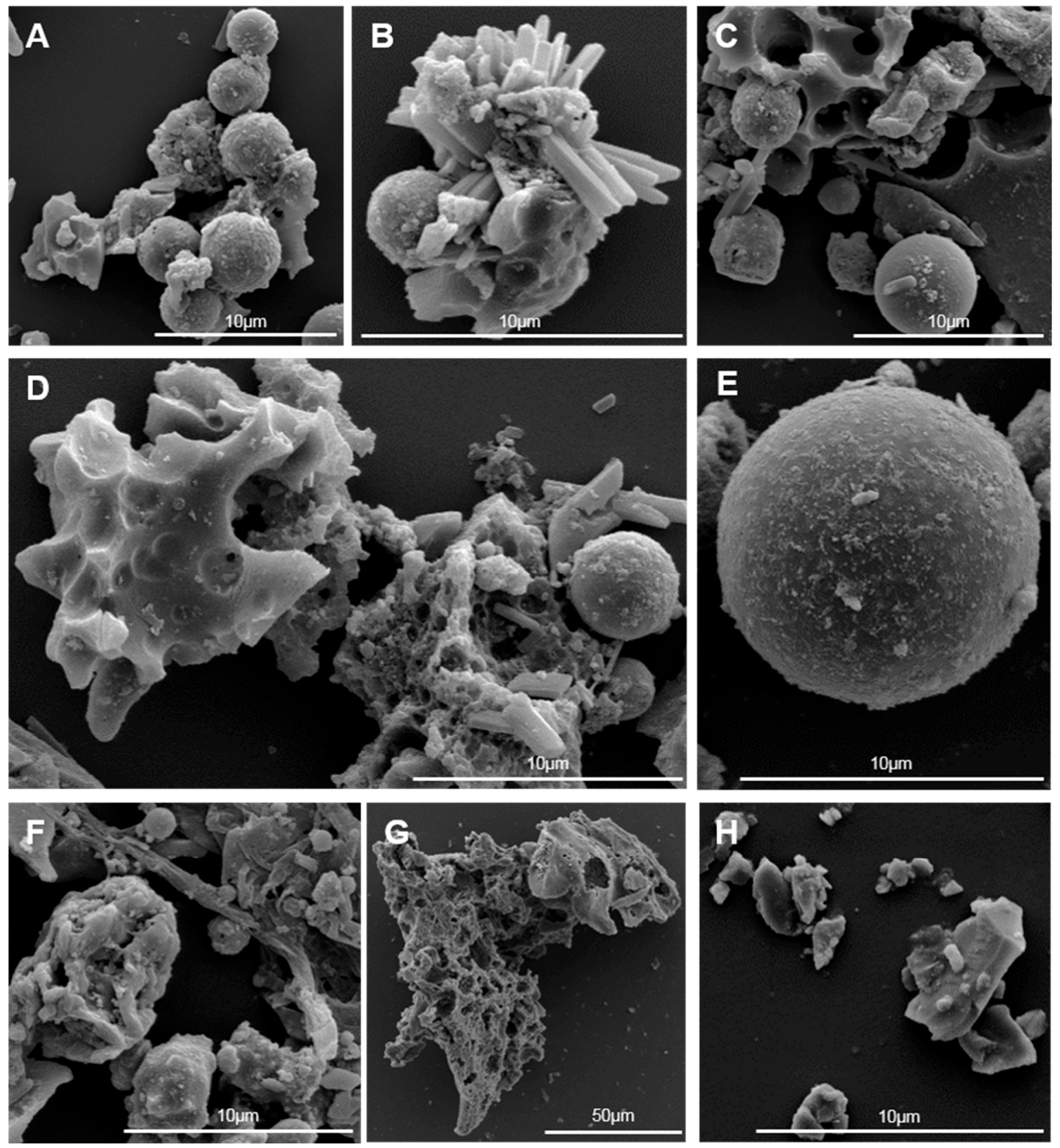

Figure 1. Field emission scanning electron microscope (FE-SEM) micrographs of size-separated coal

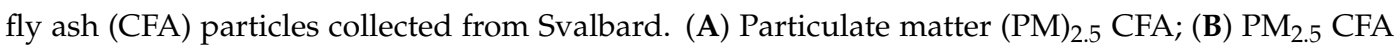
containing gypsum crystals; (C) $\mathrm{PM}_{2.5}$ CFA with large glass structures; (D) $\mathrm{PM}_{10}$ CFA containing many morphologies; (E) PM $_{10}$ CFA sphere; (F) PM 10 CFA with fibrous morphology; (G) bulk CFA; (H) crushed magnetite. 

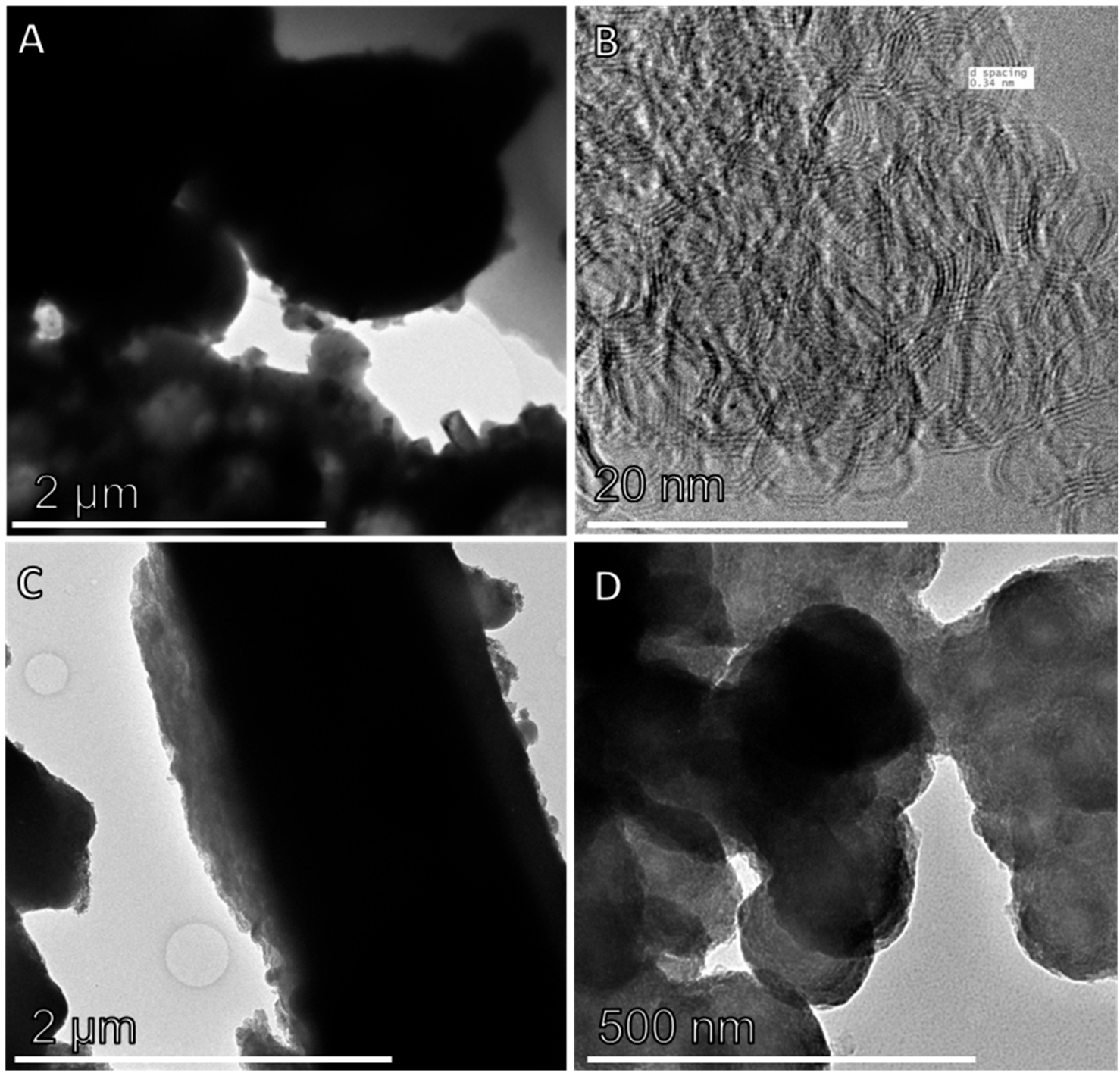

Figure 2. High-resolution transmission electron microscope (HRTEM) images of the size-separated CFA particles collected from Svalbard. (A) $\mathrm{PM}_{2.5}$ sphere in centre of image; (B) maximum magnification of TEM on $\mathrm{PM}_{2.5}$ CFA showing the lattices in the particles and a measurement of the d-spacing; $(\mathbf{C}) \mathrm{PM}_{10}$ CFA large thick "fibre" imaged in the CFA; (D) PM 10 CFA.

\subsection{Manufacture and Analysis of Svalbard CFA Leachates}

The leachates were manufactured and filtered five times for up to $48 \mathrm{~h}$. The only visible difference came from the $\mathrm{HCl}$ leachate, which was a much darker black solution compared to the other leachates. The Aberthaw CFA (control) was a much lighter grey-coloured solution. The most toxic leachates (as determined by PSA) were analysed using ICP-MS to determine what elements were leaching into the solution. $\mathrm{Na}, \mathrm{Mg}, \mathrm{Al}, \mathrm{Si}, \mathrm{K}, \mathrm{Ca}$, and Fe were all found in these leachates.

\subsection{Plasmid Scission Assay}

Exposure of both $\mathrm{PM}_{2.5}$ and $\mathrm{PM}_{10}$ Svalbard CFA caused a dose-dependent response, leading to minor damage to plasmid DNA $(\approx 30 \%)$, but magnetite (an iron oxide control) caused significantly more damage (Figure 3). 


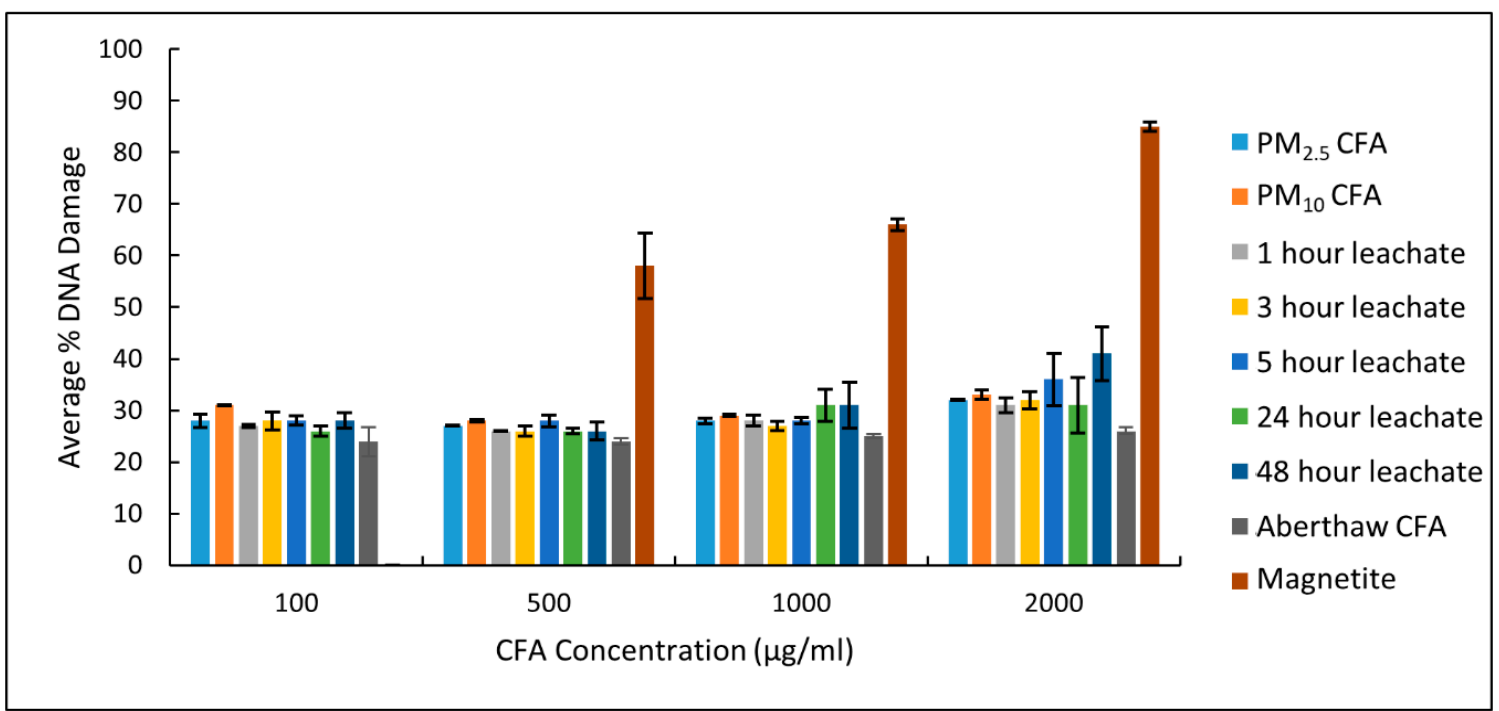

Figure 3. Damage caused to plasmid DNA by CFA suspended in $\mathrm{H}_{2} \mathrm{O}$ and an iron oxide control. The only significant $(p<0.05)$ increases in damage came from the $48 \mathrm{~h}$ leachate $(2000 \mu \mathrm{g} / \mathrm{mL})$ and the magnetite $(500,1000$, and $2000 \mu \mathrm{g} / \mathrm{mL})$. All results are minus the negative control $\left(\mathrm{H}_{2} \mathrm{O}\right)$, and the mean $(n=4)$ result is shown. Error bars display standard deviation (SD).

The leachates showed differing amounts of toxicity, which was dependent on the leaching time (the longer the time, the greater the toxicity) and the leaching solution. The results shown in Figure 4 are all for leachates using $\mathrm{PM}_{2.5} \mathrm{CFA}$ at a concentration of $2000 \mu \mathrm{g} / \mathrm{mL}$; the $\mathrm{H}_{2} \mathrm{O}$ and $\mathrm{HCl}$ leachates are the only leachates that showed a significant increase in toxicity when compared to the $\mathrm{PM}_{2.5}$ results shown in Figure 3.

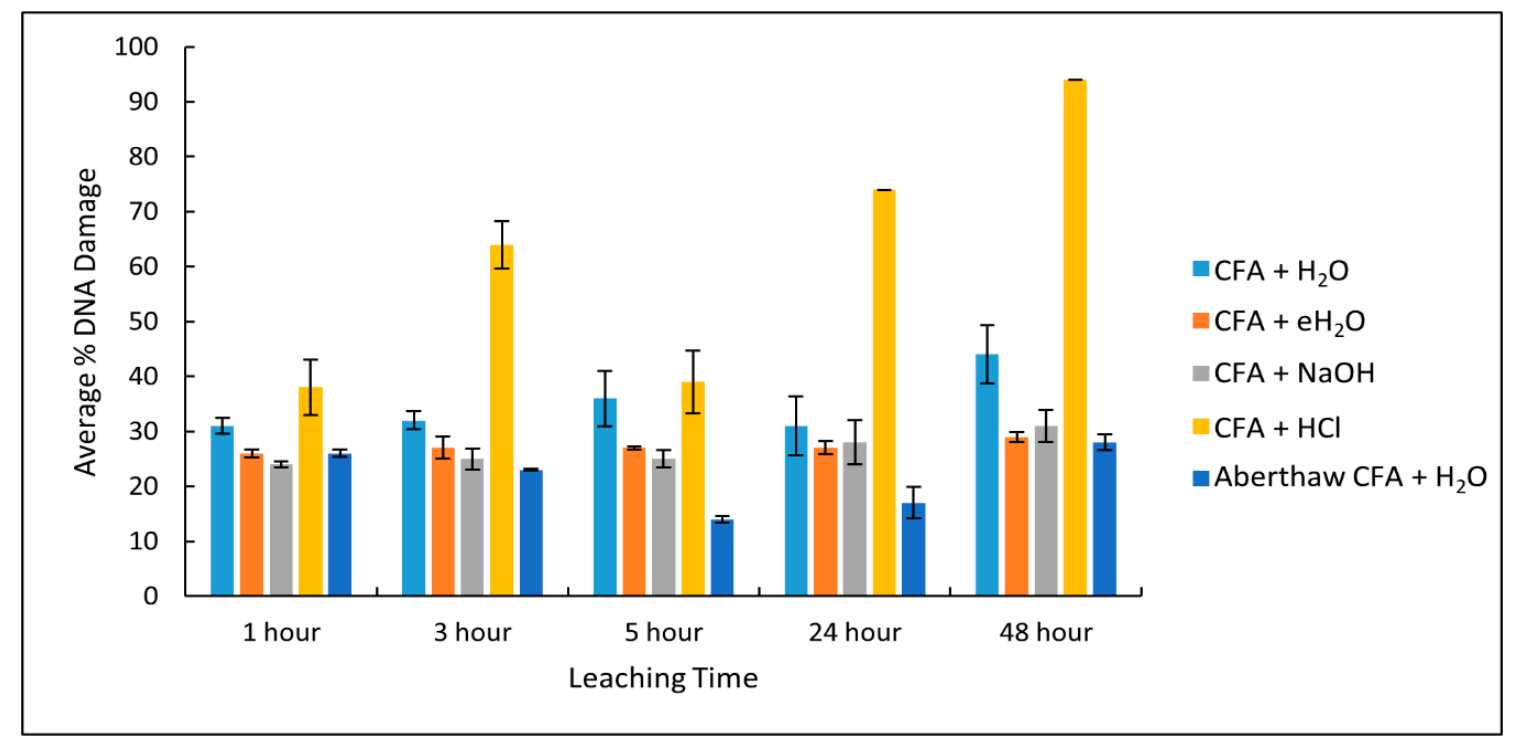

Figure 4. Damage caused to plasmid DNA by five different $\mathrm{PM}_{2.5}$ CFA leachates at $2000 \mu \mathrm{g} / \mathrm{mL}$. The only significant increase $(p<0.05)$ in damage over the leaching period came from the CFA and $\mathrm{H}_{2} \mathrm{O}$ leachate $(48 \mathrm{~h})$ and the $\mathrm{CFA}$ and $\mathrm{HCl}$ leachates $(3,24$, and $48 \mathrm{~h})$. All results are minus the negative control (the leaching condition, e.g., $\mathrm{HCl})$ and the mean $(n=4)$ result shown. Error bars display standard deviation (SD). 


\subsection{Haemolysis Assay}

In this experiment, the $\mathrm{PM}_{2.5}$ and $\mathrm{PM}_{10}$ CFA caused no haemolysis to separated RBCs from any of the donors used. The same result occurred from the magnetite, and due to the leaching solutions, the leachates could not be run through the haemolysis assay.

\subsection{Exposure to Epi-Airway Bronchial Epithelial Cells}

All the different dosing states showed an increase in TEER values with the $1 \mathrm{~h} \mathrm{HCl}$ leachate, demonstrating the greatest increase in resistance. Between each "pair" of corresponding dosing states $\left(\mathrm{PM}_{2.5}\right.$ and $\mathrm{PM}_{10}, \mathrm{H}_{2} \mathrm{O}$ leachates, and $\mathrm{HCl}$ leachates), the only significant difference in TEER values came between the $\mathrm{HCl}$ leachates; the $48 \mathrm{~h}$ TEER value was much significantly lower than the $1 \mathrm{~h}$ value (Figure 5).

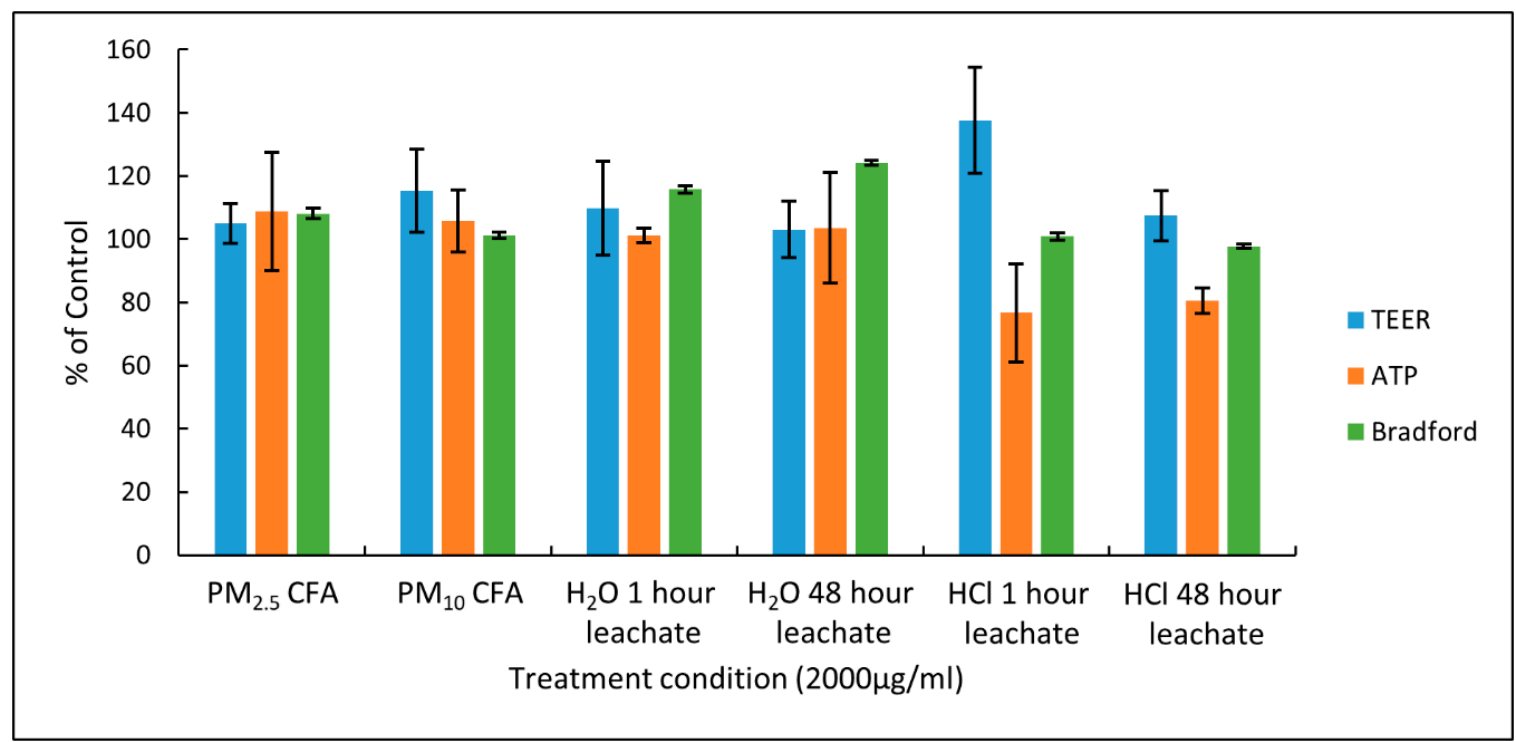

Figure 5. Trans-epithelial electrical resistance (TEER), ATP activity, and Bradford assay results following exposure of CFA and CFA leachates to EpiAirway bronchial epithelial cells. Values are given as a percentage of the control and are the mean of four repeats run on four individual cell inserts. Error bars display standard deviation (SD).

The ATP assay revealed a small change in culture viability when compared to the controls in the $\mathrm{PM}_{2.5 / 10} \mathrm{CFA}$ and the $\mathrm{H}_{2} \mathrm{O}$ leachates. The $\mathrm{HCl}$ leachates, however, showed a greater significant difference with $\approx 20 \%$ reduction when compared to the control or a TD20 response. There was no significant difference between any of the pairs of corresponding data (Figure 5).

The LDH assay (data not shown) showed no significant cytotoxicity in the media used with the cell inserts. The standard deviation of these results was particularly high and thus was deemed not to be reliable data. Higher cytotoxicity was seen in the $\mathrm{HCl}$ leachates, but this did not have any statistical significance and was simply an observation of the available data.

The protein content of apical washes was determined by the Bradford assay (Figure 5). The $\mathrm{PM}_{2.5}$ CFA and $\mathrm{H}_{2} \mathrm{O}$ leachates caused a significant increase in protein $(p<0.05)$ compared to the control, whereas the $\mathrm{PM}_{10}$ and $\mathrm{HCl}$ leachates were not significantly different to the control. The highest change in the level of protein in the samples came from the $48 \mathrm{~h} \mathrm{H}_{2} \mathrm{O}$ leachate. The average amount of protein in this sample was $186.9 \mu \mathrm{g} / \mathrm{mL}$, which was $24 \%$ greater than the control. There was, however, no significant difference between any of the pairs of corresponding data. 


\subsection{Histology}

The light microscopy (LM) histology images produced from the haematoxylin and eosin-stained tissue are shown in Figure 6; here, brief observations of each of the dosing states are given. Both of the controls $\left(\mathrm{H}_{2} \mathrm{O}\right.$ : Figure $6 \mathrm{~A}$, and $\mathrm{HCl}$ : Figure $\left.6 \mathrm{G}\right)$ showed some minor focal damage to the cells that could be used as a comparison of the other dosing conditions to see if they caused more damage or not.

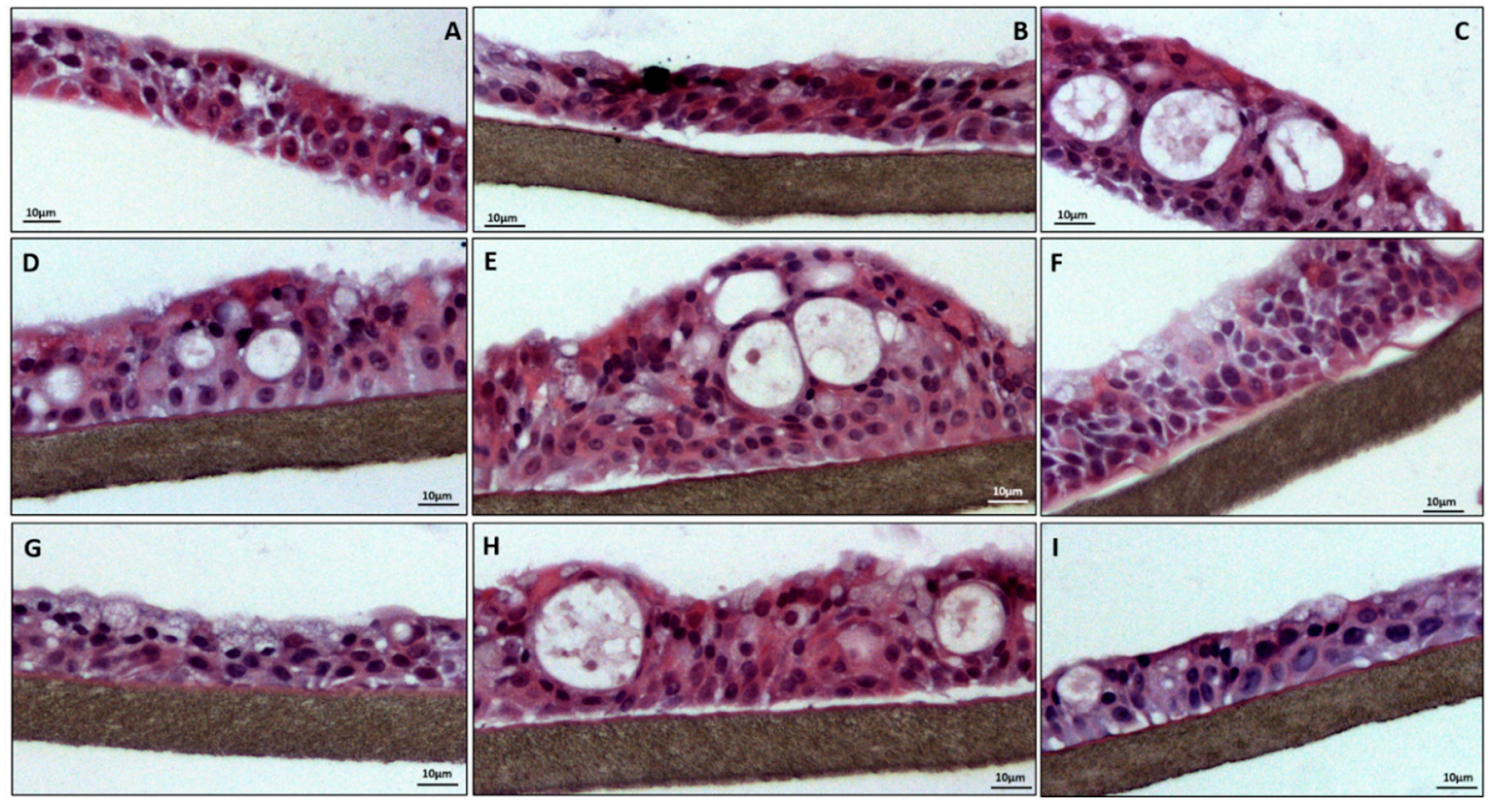

Figure 6. Bright-field images of human bronchial epithelial cells stained with haematoxylin and eosin. All images were taken following a $24 \mathrm{~h}$ exposure to CFA and CFA leachates. (A) $\mathrm{H}_{2} \mathrm{O}$ control, (B,C) $\mathrm{PM}_{2.5}$ CFA exposure, (D) $\mathrm{PM}_{10}$ CFA exposure, (E) $1 \mathrm{~h} \mathrm{H} \mathrm{H}_{2} \mathrm{O}$ CFA leachate exposure, (F) $48 \mathrm{~h} \mathrm{H}_{2} \mathrm{O}$ CFA leachate exposure, (G) $\mathrm{HCl}$ control, (H) $1 \mathrm{~h} \mathrm{HCl} \mathrm{CFA} \mathrm{leachate} \mathrm{exposure,} \mathrm{and} \mathrm{(I)} 48 \mathrm{~h} \mathrm{HCl} \mathrm{CFA}$ leachate exposure.

The histological effects following exposure to $\mathrm{PM}_{2.5} \mathrm{CFA}$ in the EpiAirway cell model is seen in Figure $6 \mathrm{~B}, \mathrm{C}$. Some of the larger aggregates of CFA (i.e., $\mathrm{PM}_{2.5} \mathrm{CFA}$ ) were found to be adhered to the surface of the bronchial epithelium, demonstrating that the particles were able to interact directly with the lung cell epithelium (Figure 6B). Goblet cell hyperplasia (GCH) was observed throughout the cell culture sample. The formation of large vacuoles was seen as a response to cell death (Figure 6C); the material of the dead cells could also be observed inside the larger vacuoles. The damage discerned by $\mathrm{LM}$ observations of the $\mathrm{PM}_{10}$ CFA-dosed cells was very focal, with areas of increased differentiation, but the overall structure remained pseudo-stratified (Figure 6D). Vacuoles that exhibited signs of cell death could be at the points of focal damage, and GCH was prominent throughout the histological sections. Compared to the $\mathrm{PM}_{2.5} \mathrm{CFA}$, which aggregated in the mucus secreted by goblet cells, the $\mathrm{PM}_{10}$ CFA aggregated with cell debris; the difference in the size fraction of the CFA could also be observed.

The focal damage caused by the $1 \mathrm{~h} \mathrm{H}_{2} \mathrm{O}$ leachate (Figure 6E) demonstrated an area of high focal damage with large vacuoles being formed from expansive regions of cells death (e.g., apoptosis). Hyperplasia could also be detected as a large "lump" around the vacuoles. GCH, production of mucus, and some cilia was also observed on the cell surface. The focal damage observed by the $48 \mathrm{~h} \mathrm{H}_{2} \mathrm{O}$ leachate (Figure 6F) varied greatly depending upon where on the cell culture sections the LM images were taken. The image shown exhibited a large amount of GCH. However, there were other areas of the section that showed a condensing of the pseudo-stratified epithelium that in turn caused the loss of cilia and goblet cells from the apical surface of the epithelium. The detachment of basal progenitor 
cells (e.g., apoptosis) was also observed, which could lead to the differentiation process observed in these cell cultures.

The $\mathrm{HCl}$ leachate control dose $(\mathrm{HCl}$, Figure $6 \mathrm{G})$ showed some focal damage with the formation of vacuoles along with significant $\mathrm{GCH}$ and small regions of squamation of the epithelium. Figure 6I shows that the $1 \mathrm{~h} \mathrm{HCl}$ leachate caused focal damage and migration of the basal cells, yet did not appear much different from the control cells. The $48 \mathrm{~h} \mathrm{HCl}$ leachate indicated a greater level of focal damage displayed by the formation of large vacuoles and hyperplasia of the cells to compensate (Figure 6H). The surface of the epithelium was significantly disrupted with large amounts of GCH affecting the normally smooth appearance of the epithelial surface. Squamation of the epithelial cells was also seen in the section, as well as more GCH, with the damage situated at the apical surface of the epithelium, whereas the basal surface remained mostly intact.

\section{Discussion}

CFA is a well-studied by-product of coal combustion in power stations. The physicochemical characteristics have been linked to inducing respiratory toxicity in humans following inhalation exposure. CFA in the inhalable-to-respirable size range usually consists mostly of spherical-shaped particles, with a chemistry of amorphous silicon dioxide (i.e., glass) containing a range of transition and heavy metals [10]. Transition metals have long been associated with the generation of ROS via Fenton chemical reactions within the human lung environment. Furthermore, chronic inhalation exposure to inhalable (i.e., PM10) and respirable (i.e., PM2.5) particles, especially the latter, have been epidemiologically associated with causing a number of pulmonary and cardiac diseases. This unique study has discovered key information about the special geochemistry of the Svalbard CFA and its related bioreactivity in vitro. In the study, we discovered that the CFA had a highly magnetic component (100\% magnetic), which was affirmed by the high amount of iron seen on the EDX spectra. The scope of the research project has thus focused on the ferrous mineral geochemistry and its potential for causing bioreactivity.

\subsection{Physicochemistry of Svalbard CFA}

The geochemical analysis first involved the "dry separation" of the bulk CFA samples into "inhalable"- and "respirable"-sized fractions as a means of determining whether these sizes could present as a "respiratory hazard". This was successfully achieved with only a small overlap between the $\mathrm{PM}_{2.5 / 10}$ particles. FE-SEM analysis revealed the presence of a small number of non-spherical particles within the $\mathrm{PM}_{2.5}$, which were larger than the required fractions. These were present due to their aerodynamic characteristics during separation, as non-spherical morphologies maintain longer airborne residency time in the separation process. Correlative HRTEM confirmed the amorphously shaped anomalies within the $\mathrm{PM}_{2.5}$ fraction as well. It is reasonable to assume that this airborne behaviour will be reproduced in the atmosphere around the power station, with the non-spherical particles remaining airborne longer than the equivalent mass spherical particles. This would require field studies being undertaken. Due to a preferential deposition in the airways, it is unlikely that the non-spherical particles will be able, on average, to penetrate as deep into the lung as their spherical mass equivalents.

\subsection{Bioreactivity of Svalbard CFA}

The PSA revealed that ROS were present through quantifying the actions of CFA-induced damage to a plasmid DNA (i.e., super-coiled morphology represented no damage) that was sensitive to ROS. The damage ranged from mild (uncoiled) to moderate (i.e., linear), and eventually $100 \%$ destruction of the DNA (i.e., fragmented). The results of the PSA showed that both PM2.5 and PM10 CFA caused minor damage to plasmid DNA. This means that without any cellular protection mechanisms, the CFA could cause relaxation of the supercoiled DNA (i.e., one site of damage to the DNA). There was a dose-dependent response; however, there was a large plateau in the data where the 
toxicity remained fairly constant $(\approx 30 \%)$. Further experiments were performed (data not shown) to see at what concentration the amount of DNA damage significantly changed. Minor toxicity could still be seen at a concentration of $10 \mu \mathrm{g} / \mathrm{mL}$, and that the toxicity began to rise above $30 \%$ at $4000 \mu \mathrm{g} / \mathrm{mL}$. Statistically, all the CFA caused significant, albeit minor, DNA damage. However, the $\mathrm{PM}_{2.5}$ and $\mathrm{PM}_{10}$ CFA were not significantly different from each other. This could be because the attempted separation of the CFA did not separate out the size fractions that were desired. As mentioned earlier, the method was not $100 \%$ accurate in its separation of CFA but was good enough to discount that the similarities in these data were caused by ineffective separation of the CFA. Another reason for the similarities in the data could be that the size of the CFA fraction did not affect the amount of damage to exposed plasmid DNA. This would make sense, as in the context of this assay, the difference between $\mathrm{PM}_{2.5}$ and PM10 size fractions were not great, and therefore the amount of damage caused by them would be similar. In the context of human exposure, however, the difference in size will affect where in the lung the CFA can be deposited to cause damage. The $\mathrm{PM}_{10}$ was inhalable but could only affect the upper respiratory tract, whereas the $\mathrm{PM}_{2.5}$ was respirable and was able to travel down into the lung and cause damage. It would also be interesting to investigate what effect the nanoparticles $\left(<\mathrm{PM}_{1}\right)$ present in the CFA would have on plasmid DNA and whether they induced significantly more damage.

The haemolysis assay further tested the premise that transition metal-induced ROS generation was occurring via the ability of the bioreactive CFA to damage DNA that was contained within human erythrocytes (i.e., red blood cells, RBCs), thus being "protected" from an ROS environment. The most bioreactive CFA PM did not lyse RBC plasma membranes and the leachates were not compatible with the assay as they were in liquid form, which caused 100\% haemolysis when exposed to RBCs. Freeze-drying the leachates and re-suspending in PBS could be a possible way around the leachate problem, and future work could focus on getting these leachates to work in the haemolysis assay.

\subsection{Lung Cell Exposure to the Svalbard CFA/Leachates}

Although two-dimensional (2D) cell systems, i.e., monocultures, have proven to be a valuable method for cell-based studies, their limitations have been increasingly recognized. Since almost all cells in the in vivo environment are surrounded by other cells and extracellular matrix in a three-dimensional (3D) fashion, 2D cell culture does not adequately consider the natural 3D environment of cells. As a result, 2D cell culture tests sometimes provide misleading and non-predictive data for in vivo responses. Consequently, our research group has been utilising 3D cell constructs, namely, the EpiAirway model, which provides physiologically relevant and reproducible results for our inhalation toxicology research.

The most "bioreactive" PM/leachates were exposed to a 3D cell culture model of the human bronchial epithelium that was used as a proxy for testing inhalation exposure in humans that mimicked both "occupational" (e.g., coal miners) and "environmental" (e.g., indoor/outdoor environment) scenarios. The most bioreactive CFA PM and leachates were shown to elicit mild to moderate damage in the bronchial region of the lung, the first site of deposition for airborne detritus not captured and/or removed by the upper RT [14].

Inflammation of the respiratory tract by cytotoxic factors (e.g., exposure to bioreactive PM/leachates) may cause an increase in the permeability of the epithelium, leading to deterioration of the epithelial barrier junction, ultimately allowing luminal substances to access the underlying tissues [15]. Changes to the permeability of the epithelium caused by alterations of the tight junctions was a reliable indicator of cytotoxic effects upon the structured components of cells [16], such as membrane channels, pumps, and other junctions [17]. TEER measurements were a reliable indicator of tight junction function in cell cultures. The permeability of the junction may be increased or decreased by the phosphorylation or de-phosphorylation of regulatory proteins, such as claudin [18]. Any decrease in TEER readings would be indicative of a disruption of the epithelial barrier. However, the TEER readings all indicated an increase in trans-epithelial resistance when compared to the controls. This was most likely caused by a defensive mechanism known as "hormesis", which has been suggested to be a beneficial biological action occurring in response to a low dose of an otherwise toxic substance [19]. In this context, it was 
a "tightening" of the tight junctions in the cells as a means to compensate for the exposure to the toxic compound. This phenomenon was most likely occurring in all of the samples tested, but was most apparent in the $1 \mathrm{~h} \mathrm{HCl}$ leachate, which exhibited the highest TEER reading (138\% of control). However, hormesis only takes place up until the point where the dose of the toxic compound becomes too much of an irritation for the cell and the process becomes reversed, whereby the cells prepare for cell death. This process was thought to be taking place with the $48 \mathrm{~h} \mathrm{HCl}$ leachate, as this showed a significant decrease in TEER readings from the $1 \mathrm{~h}$ reading.

The readings from the ATP assay can be equated to number of cells in a culture (once calibrated for each cell type), but as the EpiAirway had a multi cellular phenotype, this was not possible; however, it is a good indicator of cell number and culture viability according to metabolic activity of the cells. Increases in the levels of ATP would suggest increased metabolic activity, which could be caused by hormesis after exposure of the cells. A decrease in the ATP levels would show decreased metabolic activity most likely caused by the occurrence of cell death. Cells actively release ATP under increased stress, and this was observed to be occurring in the CFA and $\mathrm{H}_{2} \mathrm{O}$ leachates, which showed small increases in ATP versus the controls. This was an indication of the intracellular stress and the initiation of defence mechanisms. However, this stress was under the threshold of initiating damage and did not cause cell membrane damage, thereby maintaining the integrity of the cells. A decrease of $\approx 20 \%$ was seen in the $\mathrm{HCl}$ leachates, and given they were the most bioreactive leachates in the PSA, these results corroborated that damage was being caused by generation of ROS.

LDH released into the culture medium was a strong indicator of membrane instability; however, the highest level of LDH detected was $<5 \%$. The low values may be explained by the LDH being diluted in the large amount of media present. In order to obtain an accurate measurement of LDH, researchers should use $300 \mu \mathrm{L}$ of media, but in these experiments, $3 \mathrm{~mL}$ was utilised (i.e., a 10x dilution) due to necessity. Therefore, if the cell work was to be repeated, the amount of media used should be decreased to allow for a more accurate LDH reading. Unfortunately, due to the high variation caused by the low levels of cytotoxicity, these results must be deemed non-significant and cannot be used to draw reliable conclusions.

Cell debris and increased mucus secretion would increase the amount of protective mucus being secreted onto the apical surface of the bronchial epithelium to trap foreign particles and reduce their bio-reactive surface areas [20]; which could be caused by goblet cell hyperplasia (GCH). This secreted mucus contained proteins that were detected by the Bradford assay, but this assay also detected cell debris and other free proteins in the Epi-Airway, and therefore it cannot be said for sure that the cells secreted mucus onto their apical surface once exposed to PM. The higher levels of protein in the $\mathrm{H}_{2} \mathrm{O}$ leachates was most likely caused by an increase in these mucus secretions-the greatest increase was derived from the $48 \mathrm{~h}$ leachate ( $124 \%$ of control). The $\mathrm{HCl}$ leachates showed no significant difference to the control, but the $\mathrm{HCl}$ control yielded higher protein readings along with the $\mathrm{HCl}$ leachates when compared to the $\mathrm{H}_{2} \mathrm{O}$ leachates.

The inhalable and respirable fractions of CFA triggered focal damage throughout the epithelial cells. The respirable fraction caused greater damage as it could associate with the cell barrier and cause hyperplasia and cell death throughout the epithelium. The inhalable fraction caused damage to the surface epithelium, causing cells to dissociate and aggregate to the CFA. However, less overall damage to the epithelium was observed when compared to the respirable fraction. In contrast to the PM-induced effects, the "soluble" fractions from the PM2.5 leachates caused more internal harm to the cells, with greater degrees of damage and larger vacuoles formed from increased cell death. The histological analyses based upon light microscope observations pointed towards impairment of cell structure/function that was corresponding to injury/harm by the presence of ROS.

The identification of the mechanisms of injury/repair will permit the most appropriate mitigation strategies to be formulated. For example, the Svalbard mining practices for the storage of waste CFA must be reconsidered to ensure that environmental water was not allowed to permeate the waste piles to avoid "soluble bioreactive compounds" from entering the water table [21]. Furthermore, inhalation exposure 
of CFA due to the re-entrainment of CFA particles from the uncovered waste storage piles had serious implications for the respiratory health of the coal mine workers. PM2.5/10 particles have been shown to remain suspended for days and weeks in the ambient atmosphere due to Brownian motion [22], and therefore persist as inhalation hazards not only for occupational workers but also for people living in the local vicinity of a given mine [6].

\section{Conclusions}

The physicochemical properties of the Svalbard CFA determined their oxidative capabilities; the high iron content of the CFA proved to have great potential for ROS generation. ROS have been implicated in causing cell damage and in playing a major role in intracellular signalling and regulation of tight junctions in epithelial cells. The CFA and the toxic compounds that can be leached out of them were found to be cytotoxic, causing damage to the morphology of the bronchial epithelial cells in the Epi-Airway model. The results from this showed that PM2.5 CFA and the leached components of CFA could enter the epithelial barrier and cause damage to the cells. Although unseen here, previous studies have shown that CFA was able to cross the epithelium and translocate to other areas of the body. The results of this study demonstrated that Svalbard CFA was bioreactive, more so than U.K. CFA, which may have implications on the future of the use and exportation of coal from Svalbard.

Author Contributions: M.J.L. was the primary investigator and carried out the majority of the experiments and analysis. Z.C.P. performed the cell culture of the human bronchial epithelial cells and assisted with the TEER, Bradford, and ATP assays of the culture. T.P.J. performed the SEM and EDX imaging of the CFA and was a major contributor in writing the manuscript. R.A.A. performed the haemolysis assay and analysis, and also granted access to their lab facilities. K.A.B. was the main supervisor for the project and was a major contributor in writing the manuscript. All authors have read and agreed to the published version of the manuscript.

Funding: This research was funded by MRes, School of Biosciences, Cardiff University, Museum Avenue, Cardiff, CF10 3AX, United Kingdom.

Acknowledgments: Lisa Mol for collecting the CFA samples from Svalbard, and Store Norske mining company for giving permission for the samples to be collected for use at Cardiff University.

Conflicts of Interest: The authors declare no conflict of interest.

\section{References}

1. Harland, W.B. The Geology of Svalbard; The Geologcial Society: London, UK, 1997.

2. StoreNorske. Annual Report and Accounts 2013-Store Norske Spitsbergen Kulkompani AS; StoreNorske: Longyearbyen, Spitsbergen, 2013.

3. Dallmann, W.K. Geology of the land and sea areas of northern Europe Norges Geologiske Undersøkelse Special Publication. Geol. Svalbard 2007, 10, 87-89.

4. Smith, K.R.; Mehta, S. The burden of disease from indoor air pollution in developing countries: Comparison of estimates. Int. J. Hyg. Environ. Health 2003, 206, 279-289. [CrossRef] [PubMed]

5. Seames, W.S. An initial study of the fine fragmentation fly ash particle mode generated during pulverized coal combustion. Fuel Process. Technol. 2003, 81, 109-125. [CrossRef]

6. Brown, P.D.C. The Physicochemistry, Bioreactivity and Toxicity of Respirable Coal Fly Ash from UK, Poland and China; Cardiff University: Cardiff, UK, 2011.

7. Meij, R. Trace element behavior in coal-fired power plants. Fuel Process. Technol. 1994, 39, 199-217. [CrossRef]

8. Donaldson, K.; Tran, L.; Jimenez, L.A.; Duffin, R.; Newby, D.E.; Mills, N.L.; MacNee, W.; Stone, V. Combustion-derived nanoparticles: A review of their toxicology following inhalation exposure. Part. Fibre Toxicol. 2005, 2, 10. [CrossRef] [PubMed]

9. Cohn, C.A.; Fisher, S.C.; Brownawell, B.J.; Schoonen, M.A. Adenine oxidation by pyrite-generated hydroxyl radicals. Geochem. Trans. 2010, 11, 2. [CrossRef] [PubMed]

10. Jones, T.; Brown, P.; BeruBe, K.; Wlodarczyk, A.; Longyi, S. The physicochemistry and toxicology of CFA particles. J. Toxicol. Environ. Health Part A Curr. Issues 2010, 73, 341-354. [CrossRef] [PubMed]

11. Lundin, A.; Rickardsson, A.; Thore, A. Continuous monitoring of ATP-converting reactions by purified firefly luciferase. Anal. Biochem. 1976, 75, 611-620. [CrossRef] 
12. An, J.; Yin, L.; Shang, Y.; Zhong, Y.; Zhang, X.; Wu, M.; Yu, Z.; Sheng, G.; Fu, J.; Huang, Y. The combined effects of BDE47 and BaP on oxidatively generated DNA damage in L02 cells and the possible molecular mechanism. Mutat. Res. Genet. Toxicol. Environ. Mutagenesis 2011, 721, 192-198. [CrossRef]

13. Jones, T.; Moreno, T.; BeruBe, K.; Richards, R. The physicochemical characterisation of microscopic airborne particles in south Wales: A review of the locations and methodologies. Sci. Total Environ. 2006, 360, 43-59. [CrossRef] [PubMed]

14. BéruBé, K.; Prytherch, Z.; Job, C.; Hughes, T. Human primary bronchial lung cell constructs: The new respiratory models. Toxicology 2010, 278, 311-318. [CrossRef]

15. Madsen, K.L. Interactions between Microbes and the Gut Epithelium. J. Clin. Gastroenterol. 2011, 45, S111-S114. [CrossRef]

16. Hoogendoorn, B.; Bérubé, K.; Gregory, C.; Jones, T.; Sexton, K.; Brennan, P.; Brewis, I.A.; Murison, A.; Arthur, R.; Price, H.; et al. Gene and protein responses of human lung tissue explants exposed to ambient particulate matter of different sizes. Inhal. Toxicol. 2012, 24, 966-975. [CrossRef] [PubMed]

17. Ferruzza, S.; Scacchi, M.; Scarino, M.L.; Sambuy, Y. Iron and copper alter tight junction permeability in human intestinal Caco-2 cells by distinct mechanisms. Toxicol. Vitr. 2002, 16, 399-404. [CrossRef]

18. Ulluwishewa, D.; Anderson, R.C.; McNabb, W.C.; Moughan, P.J.; Wells, J.M.; Roy, N.C. Regulation of Tight Junction Permeability by Intestinal Bacteria and Dietary Components. J. Nutr. 2011, 141, 769-776. [CrossRef] [PubMed]

19. Koshy, L.; Jones, T.; BeruBe, K. Characterization and bioreactivity of respirable airborne particles from a municipal landfill. Biomarkers 2009, 14, 49-53. [CrossRef] [PubMed]

20. Chen, T.-T.; Chuang, K.-J.; Chiang, L.-L.; Chen, C.-C.; Yeh, C.-T.; Wang, L.-S.; Gregory, C.; Jones, T.; Bérubé, K.; Lee, C.-N.; et al. Characterization of the interactions between protein and carbon black. J. Hazard. Mater. 2014, 264, 127-135. [CrossRef] [PubMed]

21. Koshy, L.; Paris, E.; Ling, S.; Jones, T.; BeruBe, K. Bioreactivity of leachate from municipal solid waste landfills-assessment of toxicity. Sci. Total Environ. 2007, 384, 171-181. [CrossRef] [PubMed]

22. Bérubé, K.; Balharry, D.; Jones, T.; Moreno, T.; Hayden, P.; Sexton, K.; Hicks, M.; Merolla, L.; Timblin, C.; Shukla, A.; et al. Characterisation of airborne particulate matter and related mechanisms of toxicity: An experimental approach. Air Pollut. Rev. 2006, 3, 69-109.

Publisher's Note: MDPI stays neutral with regard to jurisdictional claims in published maps and institutional affiliations.

(C) 2020 by the authors. Licensee MDPI, Basel, Switzerland. This article is an open access article distributed under the terms and conditions of the Creative Commons Attribution (CC BY) license (http://creativecommons.org/licenses/by/4.0/). 